\title{
Higher Education in Switzerland: Predictors of Becoming Engaged in Higher Vocational or Academic Education - the Role of Workplace Factors
}

\author{
Christof Nägele*, Markus P. Neuenschwander, and Patsawee \\ Rodcharoen \\ University of Applied Sciences and Arts Northwestern Switzerland, School of Education, \\ Institute Research and Development, Centre for Learning and Socialisation, \\ Obere Sternengasse 7, 4502 Solothurn, Switzerland
}

\begin{abstract}
Context: Vocational education and training enables young people to quickly and effectively enter the labour market. To advance their careers and to develop their professional expertise even more, they must then further their education through higher vocational or higher academic education. In this study, we looked at young people at work: What motivates them to move on towards higher education? As they are engaged in their jobs, their work situations will affect their further educational engagement. We hypothesised that individuals will more likely move towards higher education if their workplaces offer learning opportunities and social support. Human capacities, attitudes, and goals at work develop mainly in informal or non-formal learning situations and in their interactions with their teams. We tested the effect of these workplace factors by taking into account additional important predictors of educational pathways, such as sociodemographic factors (social background, nationality, gender) and motivational factors (values).
\end{abstract}

${ }^{*}$ Corresponding author: christof.naegele@fhnw.ch

ISSN: 2197-8646

http://www.ijrvet.net 
Methods: Data stemmed from a multi-cohort longitudinal survey on educational decisions and educational pathways in the German part of Switzerland (BEN), running from 2012 to 2016. The selected sample consisted of 601 working individuals who were not engaged in higher education in 2014. Multinomial logistic regressions were run to test the hypothesis.

Findings: First, we found that only $35 \%$ of the individuals who wanted to become engaged in higher vocational education in 2012 became engaged up to 2016 compared with those intending to become involved in higher academic education, where the rate varied by age - from younger to older-between $45 \%$ and $70 \%$. Second, we found distinctive predictors for becoming engaged in higher vocational or academic education. Workplace factors predict engagement in higher vocational education but not sociodemographic factors, whereas sociodemographic and not workplace factors predict engagement in higher academic education. A significant predictor for both groups is the value attributed to higher education.

Conclusions: The unique contribution of this paper is to show that distinct patterns of becoming engaged in higher vocational or higher academic education exist. These results confirmed the persistent effect of sociodemographic factors that shape the pathway to higher academic education. Moreover, the results indicated that an individual's value and workplace factors contribute to enabling paths to higher vocational education, as this depends not on sociodemographic factors but on shaping the work environment that supports learning at work.

Keywords: VET, Vocational Education and Training, Lifelong Career, Professional Development, Learning Culture, Social Inequality

\section{Introduction}

Further education and training is important for individuals as well as for companies and society (Noe, Clarke, \& Klein, 2014), and it is an essential aspect of developing a meaningful work career (Duffy, Blustein, Diemer, \& Autin, 2016). Although vocational education and training enables young people to quickly and effectively enter the labour market, a drawback of this early specialisation is the reduced adaptability to changing occupational environments later (Hampf \& Woessmann, 2016). Completing further education after completing initial vocational education and training is therefore important, as this helps an individual to advance his or her career, gain access to employment, and sustain and develop the skills needed for innovation and sustainability in a changing and competitive labour market. After graduating from vocational education, not all individuals pursue further education. Engagement in further education during a person's early professional career depends on a multitude of factors. Sometimes further education is seen as being concurrent with productive work. It is the organisational learning culture that enables incidental and non-formal learning at work (Marsick \& Watkins, 2003), which also paves the way for formal education. Learning at work contributes to an individual's achievement and performance as well as to his or her future development 
(Janssens, Smet, Onghena, \& Kyndt, 2017), as the boundaries between these modes of learning overlap (Manuti, Pastore, Scardigno, Giancaspro, \& Morciano, 2015).

Individual planning for further education depends on more than merely organisational factors, such as the learning opportunities available at work. Rather, planning also depends on educational opportunities within a specific educational system, as well as on the social expectations and the particular context as reflected by an individual's origin, nationality, or gender (Becker, 2016). Furthermore, planning also depends on an individual's motivation to pursue higher education 1 (Neuenschwander, Gerber, Frank, \& Rottermann, 2012; Wigfield, Rosenzweig, \& Eccles, 2017).

Irrespective of the question of the educational system, the underlying question is, why do some individuals continue their tertiary education on the vocational pathway whereas others choose the academic pathway? Knowing why individuals follow either the vocational or the academic track to higher education helps companies and counsellors to better advise and coach individuals and to develop measures for upskilling and retaining their workforces by allocating them to higher vocational education.

\section{Predicting Participation in Higher Education}

Here, we discuss how workplace-related factors, sociodemographic factors, and an individual's value towards further education shapes becoming engaged in higher vocational or higher academic education.

\subsection{Workplace Factors}

The effects of the workplace on becoming engaged in formal education is complex (Vanthournout, Kyndt, Gijbels, \& Van den Bossche, 2015). Workplace factors affect an individual's personality, identity, and goals (Parker, 2014) and can offer opportunities for growth and positive development. This eventually leads to a more self-directed orientation, autonomy, and openness to experiences (Frese, Garst, \& Fay, 2007), including an orientation towards higher education. Overall, workplace learning has the power to expand human capacities (Evans, Guile, \& Harris, 2011).

The organisational learning culture is the background against which learning in a company is organised (Janssens et al., 2017; Kyndt \& Baert, 2013; Messmann \& Mulder, 2015) and whether the job design enables learning (Hackman \& Oldham, 1975; Raemdonck, Gijbels, \& van Groen, 2014). Work offers incidental, informal, non-formal, or formal learning opportunities that should be seen as interacting modes of learning and not as discrete entities (La Belle, 1982). A company's learning culture and an individual's abitlity to pro-actively take advantage of planned and emerging learning opportunities (Billett, 2004; Illeris, 2003) help the individual to develop the knowledge and skills needed

\footnotetext{
${ }^{1}$ Higher education on the tertiary level is divided into higher vocational education and higher academic education in Switzerland. See chapter on higher education in Switzerland in this paper.
} 
to perform his or her job, and they also motivate individuals to develop future perspectives with respect to their competence development and educational plans (Janssens et al., 2017; Kraiger, Ford, \& Salas, 1993). Positive learning experiences strengthen self-efficacy beliefs and outcome expectations (Lent, Brown, \& Hackett, 2002), and they eventually nourish an individual's desire and readiness to invest in further education. In sum, work and task immanent learning opportunities allow an individual to advance the knowledge and skills and the career (Dehnbostel, Elsholz, \& Gillen, 2007; Stalder \& Carigiet Reinhard, 2014).

Hypothesis 1: Individuals are more likely to engage in higher education if they perceive their learning opportunities at the workplace positively compared with those who work without further formal education. Learning in the workplace is embedded in a social situation. Colleagues and team members play a crucial role in shaping an individual's view of what has to be done and also on how things are done, through the development of a shared understanding of career prospects within the team. In addition, learning at work depends on the colleagues' social support (Eraut, 2007; Lave, Chaiklin, \& Lave, 1993), and impacts the reflection and definition of career goals and activities (Lent, Ezeofor, Morrison, Penn, \& Ireland, 2016; Wang \& Fu, 2015). Social support helps people to achieve their self-imposed career goals. On the one hand, social support can foster career aspirations and development (Hofmann, Stalder, Tschan, \& Häfeli, 2014). On the other hand, it can hurt an individual's career planning. As individuals become members of a team (Lave \& Wenger, 1991; Wenger, 2008), they also develop a mutual feeling of belongingness and identify with the team and with their specific roles within the team. Teams can develop an unwillingness to change the composition and role distribution even if a change may be needed (Rafferty \& Jimmieson, 2010). A team member who is planning to complete higher education may spark conflict within the team, as the team might not want to endanger its quality by allowing a team member to move away to complete higher education. Social support is a valuable resource that helps individuals to cope with workplace affordances (Frese, 1989). Taking into account that individuals have a strong need of belongingness (Deci \& Ryan, 2008), strong social support could also hinder further higher education, primarily if it results in having to leave the workgroup.

Hypothesis 2: Strong social support causes individuals to become less engaged in higher education. Strong social support is like glue that binds the team members together.

\subsection{Sociodemographic Factors}

Much research shows that educational pathways depend on social origin, nationality, or gender (Becker, 2016; Ion, Nye, \& Iliescu, 2017; Lamamra, 2017). The social origin of a family, as represented by the family's socioeconomic status, was found to be one of the major explanatory variables of educational pathways, whereby a higher socioeconomic status is associated with higher educational expectations (Johnson \& Reynolds, 2013; Neuenschwander et al., 2012). Social origin affects the transition from school to education as well as the transition to higher education (Swiss Coordination Centre 
for Research in Education [SKBF CSRE], 2014). However, some evidence also indicates that socioeconomic status does not affect a person's decision to follow a higher vocational pathway (Trede, 2016).

Hypothesis 3a: The higher a family's socioeconomic status, the greater the chance that a person in that family will complete higher academic education. We expected no effect of socioeconomic status on completing higher vocational education.

It has been found that it is harder for individuals with migrant backgrounds to access higher education. A significant effect of migration status is found in the transition to upper-secondary education (Hupka-Brunner, Sacchi, \& Stalder, 2010; Wolter \& Zumbuehl, 2017) and in the transition to tertiary education (Picot \& Hou, 2013).

Hypothesis 3b. Swiss citizens are more likely to become engaged in higher education compared with individuals with migrant backgrounds who are not Swiss citizens.

Gender stereotypes, gendered career expectations, and the socialisation process at home, during compulsory school, during career orientation, and in initial vocational education and training result in very persistent gender differences and inequalities in the Swiss labour market (Hadjar \& Aeschlimann, 2014; Lamamra, 2017). We see that many young men choose vocational education and training at the upper secondary level even if their school records would allow them to pursue general academic education.2 We expect these young men to proceed towards higher education more often after graduating from initial vocational education and training.

Hypothesis 3c: Men are more likely to participate in higher education than women are after graduating from initial vocational education and training.

\subsection{Value of Further Education}

Motivational theories on career choices propose that educational values (attainment, interest, utility) and expectations predict educational choices (Wigfield \& Cambria, 2010; Wigfield et al., 2017). Values represent the relative importance given to a specific educational choice (Brown \& Crace, 1996). If a person does not attribute high value to higher education, little chance exists that this option will be chosen. We expected that only individuals wanting to become engaged in higher education would become engaged in higher education.

Hypothesis 4: The higher the value given to higher education, the more likely that individuals be in higher education within two years.

The hypotheses are summarised in Figure 1.

\subsection{Higher Education in Switzerland}

As the hypotheses were tested based on a sample of young Swiss workers, it would be helpful to describe higher education in Switzerland briefly. Tertiary education in Switzerland features a two-tier structure: Higher vocational education is called professional education, and higher academic education is called university-based education.

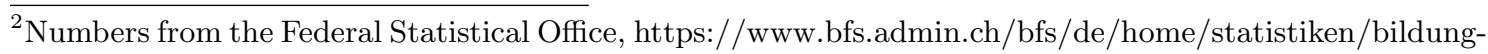
wissenschaft/bildungsindikatoren/bildungssystem-schweiz/themen/abschluesse/maturitaetsquote.html. last accessed 16 February 2018.
} 
Higher vocational education and higher academic education are at International Standard Classification of Education Level 6. In this paper, we focus on those who hold a Federal VET Diploma after having completed initial vocational education and training.

Holders of Federal VET Diplomas have three pathways to proceed with their work and educational pathways after graduation: 1) They can work and eventually attend some non-formal, often short-term courses in continuing education and training, 2) they can attend higher vocational education, or 3) they can attend higher academic education on the condition of having baccalaureate degrees.

The vocational track is for most young people the standard pathway to a diploma at the upper secondary level (Stalder \& Nägele, 2011). According to data from the Federal Statistical Office, in 2016, 63\%3 of the diplomas issued were Federal VET Diplomas, and $15 \%$ acquired professional baccalaureates 4 typically obtained during initial vocational education and training or shortly afterwards. Holders of VET diplomas acquire diplomas in higher vocational education either by passing a federal examination, based on selfreliant preparation for the examination, by attending preparatory courses, leading to a Federal Professional Education and Training (PET) diploma, or by enrolling in study programs at colleges of higher education (Nägele \& Bierschenk, 2014; State Secretariat for Education Research and Innovation [SERI], 2016). Higher academic education is accessible via a baccalaureate or after having completed a study program at a college of higher education, and it is delivered via cantonal universities, federal institutes of technology, cantonal or regional universities of applied sciences and arts, and universities of teacher education.

Higher vocational education and higher academic education are positioned as different educational pathways of equal value. Higher academic education is primarily financed by the state, higher vocational education is primarily privately financed by the participants and the employers ${ }^{5}$ According to the Federal Act on Vocational and Professional Education and Training ${ }^{6}$ and the State Secretary of Research and Innovation (SERI), the aim of higher vocational education is to develop the competences needed to handle challenging technical or managerial activities and to provide the labour market with highly skilled workers (State Secretariat for Education Research and Innovation [SERI], 2016). An individual with a Federal VET Diploma as a carpenter, for example, can complete higher vocational education to specialise in project management, the trade-specific business economy, wood technology, etc. In higher academic education, the options for the same individual are a bachelor's and master's degree in architecture or wood technology, a master's degree in engineering, or many other bachelor's and master's courses (Verband Schweizerischer Schreinermeister und Möbelfabrikanten [VSSM], 2017).

\footnotetext{
$\sqrt[3]{\text { https://www.bfs.admin.ch/bfs/en/home/statistics/education-science/diploma/upper-secondary.html, }}$ last accessed 9 February 2018

${ }^{4}$ https://www.bfs.admin.ch/bfs/de/home/statistiken/bildung-wissenschaft/bildungsindikatoren/bild ungssystem-schweiz/themen/abschluesse/maturitaetsquote.assetdetail.4282892.html, last accessed 9 February 2018

${ }^{5}$ Since January 2018 participants in higher vocational education can apply to get a refund from the state for the preparatory courses, but not for the examination fee.

6 https://www.admin.ch/opc/en/classified-compilation/20001860/index.html
} 


\section{Method}

\subsection{Participants}

Our data stemmed from two waves of a multi-cohort longitudinal questionnaire-based survey on educational decisions and educational pathways (BEN), running from 2012 to 2016 in the German part of Switzerland (Neuenschwander, Düggeli, Nägele, \& Frey, 2017). The selected sample for the analysis consisted of individuals who took part in the second and third waves of the study in 2014 and 2016.

Participants were either recruited through vocational schools (cohort one) or by sending out letters to employers and directly to potential participants (cohort two). A stratified random sample was obtained taking into account occupations and cantons. Individuals from cohort one were close to the end of their initial vocational education and training in 2014, whereas individuals from cohort two had been employed for a few years after graduating from initial vocational education and training. Participants were employed in various sectors, representing the most frequently chosen apprenticeships; for example, they were commercial employees, retail clerks, healthcare workers, social care workers, electricians, information technicians, cooks, logisticians, mechanical engineers, painters, bricklayers, and carpenters. Individuals were selected for the analyses in this paper only if they had not acquired diplomas in higher vocational or higher academic education before 2014 and if they were not completing higher education in 2014. The final sample consisted of 601 individuals.

\subsection{Measures}

\section{Engagement in Further Formal Education}

In 2014 and 2016, individuals were asked to denote all formal education programs they had completed or in which they were actively engaged at the time of the survey. Participants were asked to provide the name of the education alongside with the starting and ending date, respectively, and whether they were still engaged in this education. In higher vocational education examples include technical commercial employees, foreman in the construction business, marketing experts, or food technologists. In higher academic education examples are, a bachelor's degree in business administration or training for a curative teacher and social workers. This information was coded according to the educational level as apprenticeship, baccalaureate, higher vocational education, or higher academic education.

Based on this information, a variable with three levels was constructed: 1 'no graduation from higher education and not in higher education in 2016', $\mathrm{N}=356,59 \% ; 2$ 'having graduated from higher vocational education after 2014 or being actively engaged in higher vocational education', $\mathrm{N}=126,21 \%$; and 3 'having graduated from higher vocational education after 2014 or being actively engaged in higher academic education', $\mathrm{N}=119,20 \%$.

\section{Workplace Factors}

Task immanent learning opportunities and social support were taken from a Short Questionnaire for Job Analysis (Prümper, Hartmannsgruber, \& Frese, 1995). This questionnaire is based on the job diagnostic survey (Hackman \& Oldham, 1975), an instrument 
to assess social support (Frese \& Zapf, 1987) and an instrument for stress-related work analyses (Semmer, 1984). These sub-scales are relevant for learning at work (Kammermann, Stalder, \& Hättich, 2011; Keller, Meier, Gross, \& Semmer, 2015; Nägele, 2013; Stalder \& Carigiet Reinhard, 2014).

Learning opportunities at work were assessed with three items (Prümper et al., 1995), for example, 'I can learn a lot of new things at work' based on the skill variety at work. The response scale ranged from 1 'not at all' to 5 'completely', Cronbach's alpha $=.77$, mean $=3.8 ;$ standard deviation $=.83, \mathrm{~N}=601, \min =1, \max =5$, and median $=4$.

Social support was assessed with three items (Prümper et al., 1995), for example, 'I can count on my colleagues when it gets difficult at work'. The response scale ranged from 1 'not at all' to 5 'completely', Cronbach's alpha $=.77$, mean $=4.1$, standard deviation $=.76, \mathrm{~N}=597, \min =1, \max =5$, and median $=4$.

\section{Sociodemographic Factors}

0pt The socioeconomic status of the parents was used as a proxy for the social origin. The family's international socioeconomic index was calculated as the highest value of the fathers' and mothers' socioeconomic statuses. This information was based on the parents' occupations, coded according to the classification scheme of the Federal Institute of Statistics. Mean $=51.7$; standard deviation $=20.9 ; \mathrm{N}=601, \min =14.2$, $\max =$ 88.7 , median $=56$.

The individuals were asked to name their citizenship according to their passport or identity card. Individuals holding a Swiss and individuals holding a Swiss and any other national passport or identity card were categorised as Swiss citizens. Non-Swiss citizens were those without a Swiss passport or identity card. $\mathrm{N}=601$, Swiss citizenship $\mathrm{N}=$ $550,91 \%$, non-Swiss citizenship $\mathrm{N}=51,9 \%$.

Gender was assessed with two categories, female and male. $\mathrm{N}=601$, female $\mathrm{N}=371$, $62 \%$, male $\mathrm{N}=230,38 \%$.

\section{Value of Higher Education}

The value given to further formal education was measured according to Wigfield et al. (2017) with three items. 'I consider further education and training for me as... a) useful, b) important, c) attractive'. The response scale ranged from 1 'not at all true' to 6 'completely true', Cronbach's alpha $=.84$. Mean $=5.1$, standard deviation $=.83, \mathrm{~N}=$ $600, \min =1, \max =6$, and median $=5$.

\section{Cohort/Age}

The cohort was included in the analyses, as individuals within the two cohorts represented two different career situations. Cohort one had finished initial vocational education and training between 2012 and 2014, whereas individuals from cohort two had been working for several years on their jobs. The cohort corresponded with the age of the individual, as the participants were younger in cohort one than in cohort two. Cohort one $\mathrm{N}=350,57 \%$, age (in 2014) $=21.84$ years, standard deviation $=1 ., 7$ Cohort two $\mathrm{N}=251,43 \%$, age $($ in 2014$)=27.7$ years, standard deviation $2.5, \mathrm{t}(646)=-21.95$, $\mathrm{p}<.01$. 


\section{Results}

\subsection{Expectations and Realisation of Educational Aspirations}

To describe the sample according to their educational expectations, we first report the results from cross-tabulating educational expectations in 2014 and their realisation in 2016. The expectation of achieving a particular formal educational type was assessed in 2014 with a single item: 'What is the highest degree you are going to attain in your educational career?'. The response options were tracheotomised: 1 'No further formal education, I am fine with a diploma in initial vocational education and training with or without a baccalaureate (graduation on the upper secondary level)', 2 'Federal diploma in higher vocational education', and 3 'Diploma in higher academic education'. Table 1 reveals that only $35 \%$ of the individuals who expected in 2014 to achieve higher vocational education were two years later engaged in higher vocational education. For individuals who expected in 2014 to obtain higher academic education, the rate was higher, and it differed between the two cohorts. The rate was $45 \%$ for the younger cohort and $70 \%$ for the older cohort. The picture was different for those who told us in 2014 that they were planning to stay working, without further formal education at the tertiary level. In $94 \%$ of the cases, these individuals were two years later still working and not in higher education. The result also indicated that only a few individuals switched between higher vocational education and higher academic education. In addition, if individuals switched, they switched from higher academic education in 2014 to higher vocational education two years later as can be seen in cohort one featuring the younger individuals.

Overall, these descriptive results indicated that many individuals who told us in 2014 that they expected to attain diplomas in higher vocational education were not engaged in higher vocational education two years later. This was different for individuals who told us that they expected to be in higher academic education. A larger percentage of these individuals were in higher academic education, especially in the older population (cohort two). 
Table 1: Educational expectations in 2014 and engagement in higher education in 2016

\begin{tabular}{|c|c|c|c|c|c|c|}
\hline & & & $\begin{array}{l}\text { Higher } \\
\text { vocational } \\
\text { education }\end{array}$ & $\begin{array}{l}\text { Higher } \\
\text { academic } \\
\text { education }\end{array}$ & $\begin{array}{l}\text { No } \\
\text { higher } \\
\text { education }\end{array}$ & \\
\hline $\begin{array}{l}\text { Higher } \\
\text { vocational } \\
\text { education }\end{array}$ & Cohorts $1 \& 2^{*}$ & $\begin{array}{l}\mathrm{N} \\
\%\end{array}$ & $\begin{array}{l}93 \\
35 \%\end{array}$ & $\begin{array}{l}9 \\
3 \%\end{array}$ & $\begin{array}{l}165 \\
62 \%\end{array}$ & $\begin{array}{l}266 \\
100 \%\end{array}$ \\
\hline \multirow[t]{3}{*}{$\begin{array}{l}\text { Higher } \\
\text { academic } \\
\text { education }\end{array}$} & Cohort $1^{* *}$ & $\begin{array}{l}N \\
\text { expected } N \\
\% \\
\text { adj. residual }\end{array}$ & $\begin{array}{l}16 \\
11.9 \\
17 \% \\
1.8\end{array}$ & $\begin{array}{l}44 \\
55.2 \\
46 \% \\
-3.3\end{array}$ & $\begin{array}{l}36 \\
28.9 \\
37 \% \\
2.3\end{array}$ & $\begin{array}{l}96 \\
96 \\
100 \%\end{array}$ \\
\hline & Cohort 2 & $\begin{array}{l}N \\
\text { expected } N \\
\% \\
\text { adj. residual }\end{array}$ & $\begin{array}{l}7 \\
11.1 \\
8 \% \\
-1.8\end{array}$ & $\begin{array}{l}63 \\
51.8 \\
70 \% \\
3.8\end{array}$ & $\begin{array}{l}20 \\
27.1 \\
212 \\
-2.8\end{array}$ & $\begin{array}{l}90 \\
90 \\
100 \%\end{array}$ \\
\hline & Cohort $1 \& 2$ & $\begin{array}{l}N \\
\%\end{array}$ & $\begin{array}{l}23 \\
12 \%\end{array}$ & $\begin{array}{l}107 \\
58 \%\end{array}$ & $\begin{array}{l}56 \\
30 \%\end{array}$ & $\begin{array}{l}186 \\
100 \%\end{array}$ \\
\hline $\begin{array}{l}\text { No higher } \\
\text { education }\end{array}$ & Cohort $1 \& 2^{* * *}$ & $\begin{array}{l}\mathrm{N} \\
\%\end{array}$ & $\begin{array}{l}7 \\
5 \%\end{array}$ & $\begin{array}{l}1 \\
1 \%\end{array}$ & $\begin{array}{l}124 \\
94 \%\end{array}$ & $\begin{array}{l}132 \\
100 \%\end{array}$ \\
\hline
\end{tabular}

Legend. ${ }^{*} \chi^{2}(2)=2.44, p=.30 ; * * \chi^{2}(2)=11.29, p=<01 ; * * * \chi^{2}(2)=1.47, p=.48$; Separate frequencies and residuals for the cohorts are presented only if the $\chi^{2}$ is statistically significant. Overall: $N=601$, cases with missing data $N=17$.

\subsection{Results Predicting Participation in Higher Education}

To test the hypotheses, we calculated three multinomial regression models: model 1 with only the sociodemographic variables, model 2 with the value variable added, and model 3 with the workplace variables added. The analyses were run using SPSS 25 (IBM Corp., 2017). The results are summarised in Table 2. Due to the number of predictor variables in the model, some cells have zero frequencies, which implies that the standard errors need to be checked for unusually high values (Field, 2013). The results in Table 1 indicate that no conspicuous standard errors exist. It is notable that sociodemographic variables alone could not explain engagement in higher vocational education (model 1). Gender, which was a significant predictor of higher vocational education in model 1, had no effect after we controlled for learning opportunities and social support (model 3 ). The results revealed two distinct sets of predictor variables for higher vocational education and higher academic education. Learning at the workplace and (marginally significant) team support predicted engagement in higher vocational education, whereas social origin and nationality predicted engagement in higher academic education. The value attributed to further higher education was predictive for both higher vocational education and higher academic education. 
The hypotheses are discussed in detail based on model 3, and the results are summarised in Figure 1. Hypothesis 1 was partly confirmed, as a positive effect of learning opportunities on engagement in higher vocational education was found, odds ratio $=$ $1.71, p<.01$, but this was not so for higher academic education, odds ratio $=.80, p$ $=.14$. Hypothesis 2 was not confirmed, as social support had no significant effect on engagement in higher education, neither for higher vocational education, odds ratio $=$ $.74, p=.06$, nor for higher academic education, odds ratio $=1.02, p=.89$. However, the result for higher vocational education was only marginally non-significant, indicating that social support might hinder further higher vocational education. Hypothesis $3 \mathrm{a}$ was confirmed, as higher socioeconomic status predicted engagement in higher academic education, odds ratio of $1.02, p=.02$, but not in higher vocational education, odds ratio $=1.00, p=.89$. Hypothesis $3 \mathrm{~b}$ was partly confirmed, as a higher chance existed for Swiss citizens to complete higher academic education, odds ratio of $4.51, p=.01$, but no effect was found for higher vocational education, odds ratio $=2.12, p=.08$. Hypothesis $3 \mathrm{c}$ was not confirmed, as gender had no effect on being engaged in higher education, neither in higher academic education, odds ratio of .66, $p=.08$, nor in higher vocational education, odds ratio $=.72, p=.15$. Hypothesis 4 was confirmed, as the value had a substantial effect on becoming engaged in higher academic education, odds ratio $=2.84$, $p<.01$, or in higher vocational education, odds ratio $=2.88, p<.01$. The cohort was used as a control variable with an effect on being engaged in higher academic education, odds ratio $=.38, p<.01$, indicating that younger individuals from cohort one were less likely to attend higher academic education within two years. It takes more time to start with higher academic education, for example, because individuals need to acquire vocational baccalaureates before gaining access to it. In addition, formal education programs typically start once a year, in autumn, whereas higher education programs can often be completed on a short-term basis. 


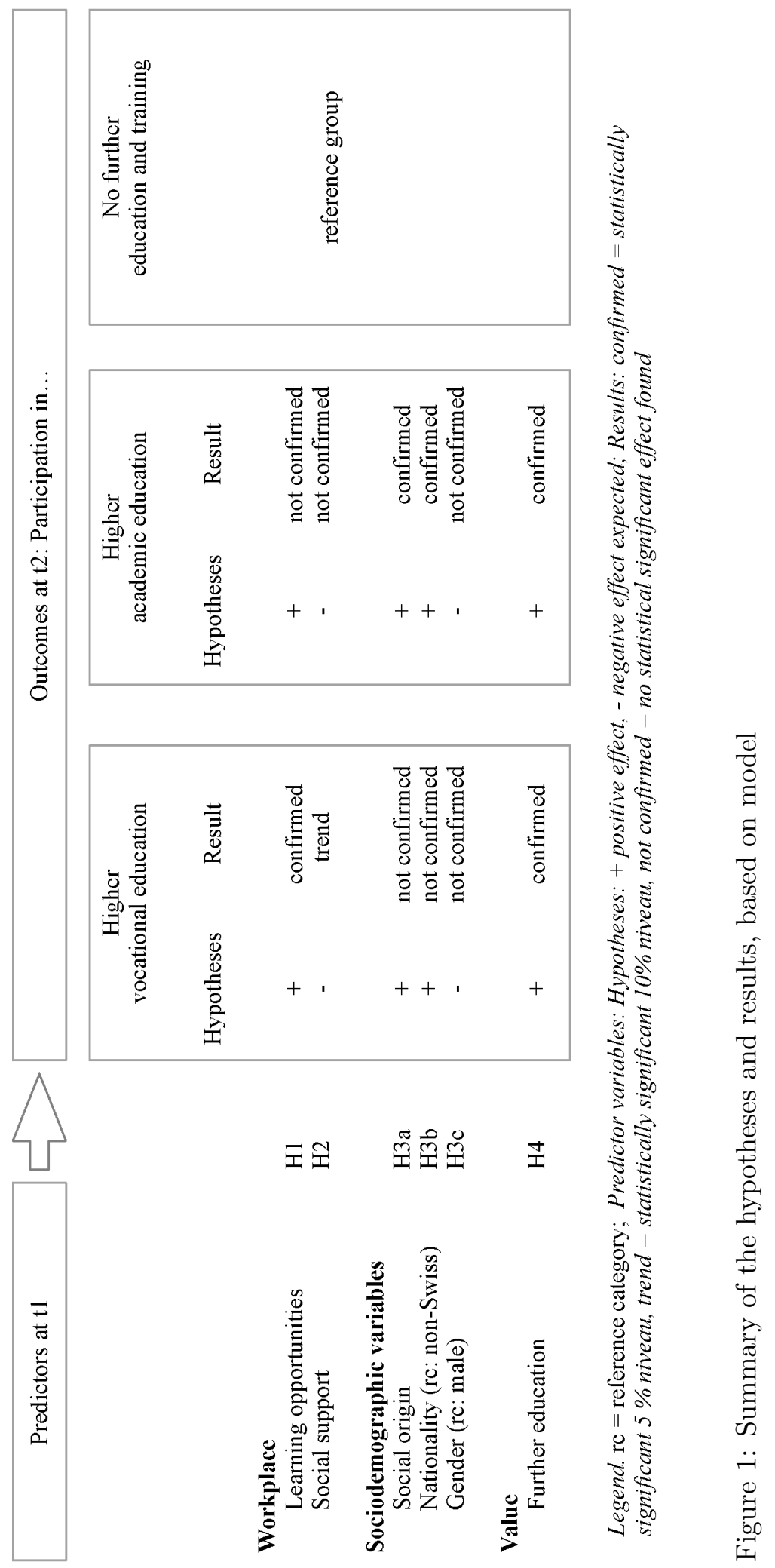




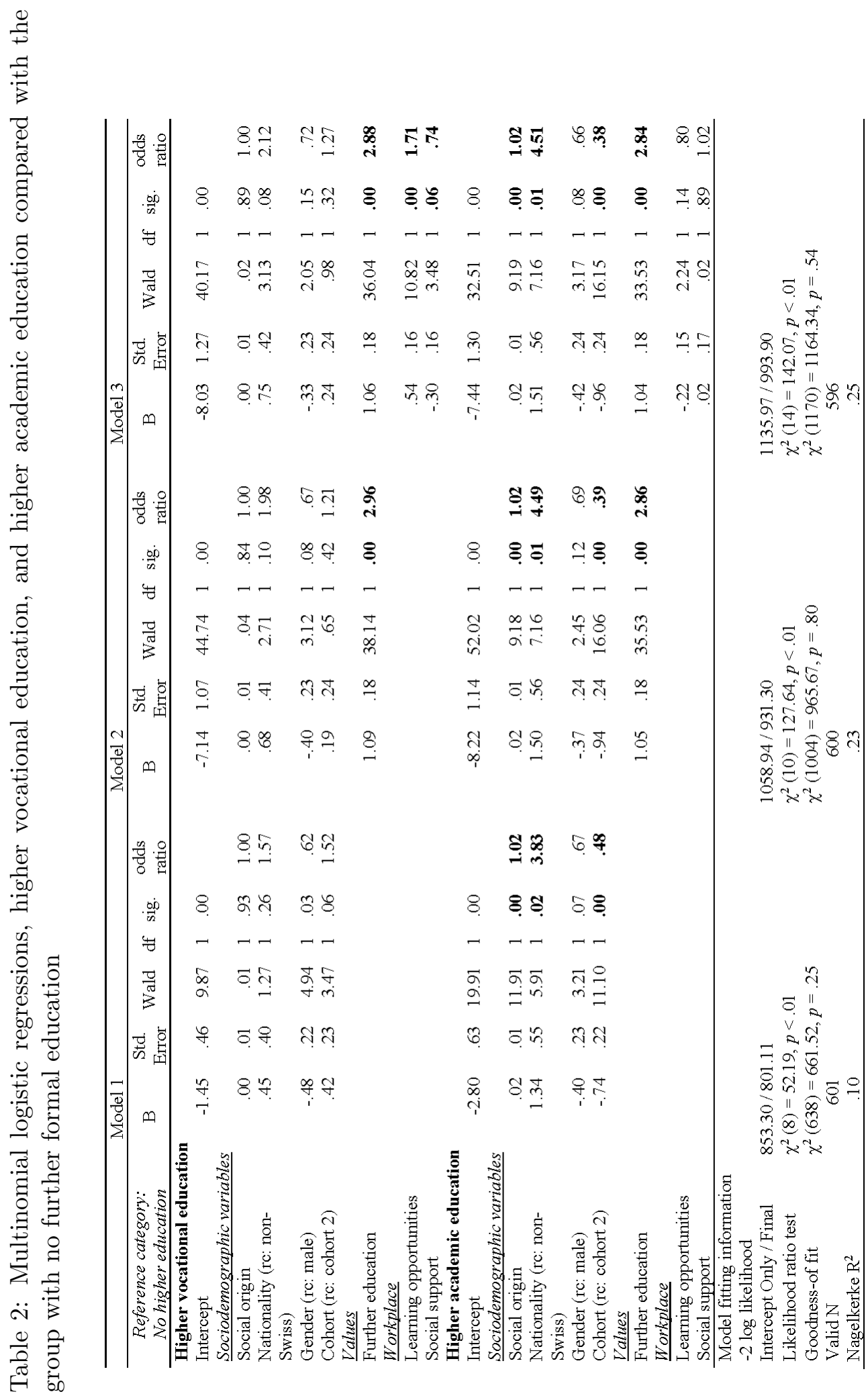




\section{Discussion}

In this paper, we examined the effects of workplace characteristics (social support, learning opportunities), of sociodemographic factors (social origin, nationality, gender), and of the value assigned to higher education as predictors of engagement in higher education.

We found predictors of being engaged in higher education that differ between higher vocational and higher academic education. Following an individual's graduation from initial vocational education and training, workplace factors predict engagement in higher vocational education, and sociodemographic factors explain engagement in higher academic education. A significant predictor for both groups is a high value attributed to higher education.

Within the two years during the course of the study, we found that many individuals with the expectation of attaining higher vocational diplomas in 2014 were not engaged in 2016 in higher vocational education (66 \%), which was different for higher academic education, where fewer individuals were not yet involved in higher academic education ( $55 \%$ in the younger cohort, $28 \%$ in the older cohort). This signifies that many individuals with the expectation of achieving higher education diplomas were not yet actively engaged in higher education.

Individuals who see learning options at the workplace will more likely complete higher vocational education rather than continue working. Positive social support seemed to hinder higher vocational education, although this result needs to be interpreted cautiously, as it is only marginally significant. Contrary to our expectation, the sociodemographic variables of social origin, nationality, and gender had no significant effect on completing higher vocational education. Higher vocational education seems to be less socially selective compared with higher academic education. The effect of learning opportunities at work is of greater importance. This finding is in line with reports on the positive effects of informal learning on an individual's motivation to develop specific job-related competences (Janssens et al., 2017). This finding points to the considerable function of workplace learning as a way of motivating employees to develop their professional competences, which is the responsibility of individuals and organisations. A proactive individual can create learning opportunities, for example, through job crafting (Wrzesniewski \& Dutton, 2001). It seems to be worthwhile for organisations to reflect on how to support learning in the workplace and to discuss and implement supportive learning cultures. Organisations with learning cultures can create, acquire, and transfer knowledge and can reflect this knowledge and change its behaviour (Garvin, 1993), as this positively affects commitment and intrinsic motivation (Joo \& Lim, 2009). To promote engagement in higher vocational education, it seems necessary to design a workplace that is favourable for learning. Only if individuals experience that learning at work is possible will they invest in further learning in higher vocational education, as they can expect the transfer of the new knowledge and skills to the workplace to be possible.

The picture for individuals engaged in higher academic education was somewhat different, partly as expected. The sociodemographic variables of socioeconomic status and nationality were as expected the best predictors, besides the value of further education. However, the workplace factors were of no importance. 


\section{Limitations}

Although the study achieved its aim and the hypotheses could be tested, some limitations should be pointed out. It would be interesting and necessary to replicate these findings for specific trades. Despite the large sample size, these analyses would result in even more cells with zero frequencies. Replications should be done with a focus on specific trades to reduce the variance in the sample selected. Workplace factors were measured as self-reports in this study. To achieve a more in-depth understanding, we suggest that a more detailed measurement of workplace learning, social support, and satisfaction, moreover from different perspectives and as repeated measures over a more extended period, could provide valuable insights into how workplace factors shape motivation for engagement in higher education.

\section{Conclusion}

The examination of the realisation of plans for higher education over time and relating individual and workplace factors have pointed out considerable differences between individuals in higher vocational education and higher academic education. Individuals are engaged in higher academic education due to their social origins and nationalities. This finding adds to the existing knowledge that native people from families with better access to education have a higher likelihood of attending higher academic education. These processes of social exclusion and social selection processes seem to be very persistent.

On the other hand, we see that higher vocational education seems to offer socially nondiscriminating access to higher vocational education, even if higher vocational education is financed primarily privately by the participants and the employers. Higher vocational education is positioned as a provider of highly skilled workers for the labour market. We find that the chance to become involved in higher vocational education increases if individuals have learning opportunities in the workplace and if their colleagues do not hinder them if their social integration is too tight. Instead, it is the work environment, namely the perception of learning opportunities and social support, that promote higher vocational education. Individuals wanting to complete higher vocational education should try to find or craft a workplace that allows them to learn. In addition, companies that want their employees to move towards higher vocational education should support them by designing workplaces as learning places. The unique contribution of this paper is to compare these two distinct patterns of becoming engaged in higher vocational or higher academic education.

From a theoretical point of view, we need to look at predictors of educational pathways besides sociodemographic variables. We should integrate variables related to workplace factors in our theories and empirical models.

From a policy perspective, this study described an example where higher vocational education was designed as a parallel strand to higher academic education, which is chosen by individuals with a distinct profile. It is noticeable that some people seem to be motivated by the work environment to continue their education in higher education, whereas others are motivated by heritage, which is linked to status. 
Overall, we still need to find answers to deal with the finding that social origin and, in our results especially, nationality are important factors that steer access to higher academic education but not to higher vocational education. It might be worth looking at selection and socialisation processes during vocational education and training more closely to understand the discriminative processes that contribute to the discrimination of individuals from a motivational perspective. Most importantly, a closer look at factors that hinder individuals at work from becoming engaged in higher vocational education is necessary. We have seen that many individuals who wish to complete higher vocational education do not do this. These individuals start their higher education as a result of an appropriate job design. Learning opportunities in the workplace trigger their engagement, factors that can be shaped by both individuals and companies.

\section{References}

Becker, R. (2016). Soziale Ungleichheit von Bildungschancen und Chancengerechtigkeit - Eine Reanalyse mit bildungspolitischen Implikationen [Social inequality of educational opportunities and equal opportunities - A reanalysis with implications for education policy]. In R. Becker \& W. Lauterbach (Eds.), Bildung als Privileg. Erklärungen und Befunde zu den Ursachen der Bildungsungleichheit (pp. 183-219). Wiesbaden, DE: Springer VS. Retrieved from http://link.springer.com/10.1007/9783-658-11952-2

Billett, S. (2004). Workplace participatory practices: Conceptualising workplaces as learning environments. Journal of Workplace Learning, 16(6), 312-324. https://doi. org/10.1108/13665620410550295

Brown, D., \& Crace, R. K. (1996). Values in life role choices and outcomes: A conceptual model. The Career Development Quarterly, 44(3), 211-223. https://doi.org/10.1002 $/ \mathrm{j} .2161-0045.1996 . t b 00252 . \mathrm{x}$

Deci, E. L., \& Ryan, R. M. (2008). Self-determination theory: A macrotheory of human motivation, development, and health. Canadian Psychology, 49(3), 182-185. https://doi.org/10.1037/a0012801

Dehnbostel, P., Elsholz, U., \& Gillen, J. (2007). Kompetenzerwerb in der Arbeit. Perspektiven arbeitnehmerorientierter Weiterbildung [Acquisition of competence in work. Perspectives of employee-oriented further education and training]. Berlin, DE: edition sigma.

Duffy, R. D., Blustein, D. L., Diemer, M. A., \& Autin, K. L. (2016). The psychology of working theory. Journal of Counseling Psychology, 63(2), 127-148. https://doi.org/1 $0.1037 / \mathrm{cou} 0000140$

Eraut, M. (2007). Learning from other people in the workplace. Oxford Review of Education, 33(4), 403-422. https://doi.org/10.1080/03054980701425706

Evans, K., Guile, D., \& Harris, J. (2011). Rethinking work-based learning: For education professionals and professionals who educate. In M. Malloch, L. Cairns, K. Evans, \& B. N. O'Connor (Eds.), The SAGE handbook of workplace learning. London, UK: SAGE Publications Ltd. 
Field, A. (2013). Discovering statistics using IBM SPSS Statistics (4th ed.). London, UK: SAGE Publications Ltd.

Frese, M. (1989). Gütekriterien der Operationalisierung von sozialer Unterstützung am Arbeitsplatz [Criteria for the quality of the operationalisation of social support at the workplace]. Zeitschrift für Arbeitswissenschaft, 43, 112-122.

Frese, M., Garst, H., \& Fay, D. (2007). Making things happen: Reciprocal relationships between work characteristics and personal initiative in a four-wave longitudinal structural equation model. Journal of Applied Psychology, 92(4), 1084-1102. https://doi.org/10.1037/0021-9010.92.4.1084

Frese, M., \& Zapf, D. (1987). Eine Skala zur Erfassung von sozialen Stressoren am Arbeitsplatz [A scale for recording social stressors at the workplace]. Zeitschrift für Arbeitswissenschaft, 41(3), 134-141.

Garvin, D. A. (1993). Building a learning organization. Harvard Business Review, 71(4), 78-91.

Hackman, J. R., \& Oldham, G. R. (1975). Development of the job diagnostic survey. Journal of Applied Psychology, 60(2), 159-170. https://doi.org/10.1037/h0076546

Hadjar, A., \& Aeschlimann, B. (2014). Gender stereotypes and gendered vocational aspirations among Swiss secondary school students. Educational Research, 57(1), 22-42. https://doi.org/10.1080/00131881.2014.983719

Hampf, F., \& Woessmann, L. (2016). Vocational vs. general education and employment over the life-cycle: New evidence from PIAAC. München, DE: Center for Economic Studies \& Ifo Institute.

Hofmann, C., Stalder, B. E., Tschan, F., \& Häfeli, K. (2014). Support from teachers and trainers in vocational education and training: The pathways to career aspirations and further career development. International Journal for Research in Vocational Education and Training, 1(1), 1-20. https://doi.org/10.13152/IJRVET.1.1.5

Hupka-Brunner, S., Sacchi, S., \& Stalder, B. E. (2010). Social origin and access to upper secondary education in Switzerland: A comparison of company-based apprenticeship and exclusively school-based programmes. Schweizerische Zeitschrift für Soziologie, 36(1), 11-31.

IBM Corp. (2017). IBM SPSS Statistics for Mac, Version 25.0. 0.1. Armonk, NY, US: IBM Corp.

Illeris, K. (2003). Workplace learning and learning theory. Journal of Workplace Learning , 15(4), 167-178. https://doi.org/10.1108/13665620310474615

Ion, A., Nye, C. D., \& Iliescu, D. (2017). Age and gender differences in the variability of vocational interests. Journal of Career Assessment, 1-17. https://doi.org/10.1177/1 069072717748646

Janssens, L., Smet, K., Onghena, P., \& Kyndt, E. (2017). The relationship between learning conditions in the workplace and informal learning outcomes: A study among police inspectors. International Journal of Training and Development, 21(2), 92112. https://doi.org/10.1111/ijtd.12095

Johnson, M. K., \& Reynolds, J. R. (2013). Educational expectation trajectories and attainment in the transition to adulthood. Social Science Research, 42(3), 818-835. https://doi.org/10.1016/j.ssresearch.2012.12.003 
Joo, B.-K., \& Lim, T. (2009). The effects of organizational learning culture, perceived job complexity, and proactive personality on organizational commitment and intrinsic motivation. Journal of Leadership \& Organizational Studies, 16(1), 48-60. https://doi.org/10.1177/1548051809334195

Kammermann, M., Stalder, B. E., \& Hättich, A. (2011). Two-year apprenticeships a successful model of training? Journal of Vocational Education and Training, 63(3), 377-396. https://doi.org/10.1080/13636820.2011.586130

Keller, A. C., Meier, L. L., Gross, S., \& Semmer, N. K. (2015). Gender differences in the association of a high quality job and self-esteem over time: A multiwave study. European Journal of Work and Organizational Psychology, 24(1), 113-125. https://doi.org/10.1080/1359432X.2013.865118

Kraiger, K., Ford, J. K., \& Salas, E. (1993). Application of cognitive, skill-based, and affective theories of learning outcomes to new methods of training evaluation. Journal of Applied Psychology, 78(2), 311-328. https://doi.org/10.1037//0021-9010.78.2.311

Kyndt, E., \& Baert, H. (2013). Antecedents of employees' involvement in work-related learning: A systematic review. Review of Educational Research, 83(2), 273-313. https://doi.org/10.3102/0034654313478021

La Belle, T. J. (1982). Formal, nonformal and informal education: A holistic perspective on lifelong learning. International Review of Education, XXVlll, 159-175.

Lamamra, N. (2017). Vocational education and training in Switzerland: A gender perspective. From socialisation to resistance. Educar, 53(2), 379-396. https://doi.org/1 $0.5565 / \mathrm{rev} / \mathrm{educar} .863$

Lave, J., Chaiklin, S., \& Lave, J. (1993). The practice of learning. In K. Illeris (Ed.), Understanding practice: Perspectives on activity and context (pp. 200210). Oxon, UK: Routledge.

Lave, J., \& Wenger, E. (1991). Situated learning: Legitimate peripheral participation. New York, NY, US: Cambridge University Press.

Lent, R. W., Brown, S. D., \& Hackett, G. (2002). Social cognitive career theory. In D. Brown (Ed.), Career choice and development (pp. 255-311). San Francisco, CA, US: Jossey-Bass.

Lent, R. W., Ezeofor, I., Morrison, A. M., Penn, L. T., \& Ireland, G. W. (2016). Applying the social cognitive model of career self-management to career exploration and decision-making. Journal of Vocational Behavior, 93, 47-57. https://doi.org/10.1016 /j.jvb.2015.12.007

Manuti, A., Pastore, S., Scardigno, A. F., Giancaspro, M. L., \& Morciano, D. (2015). Formal and informal learning in the workplace: A research review. International Journal of Training and Development, 19(1), 1-17. https://doi.org/10.1111/ijtd.120 44

Marsick, V. J., \& Watkins, K. E. (2003). Demonstrating the value of an organization's learning culture: The dimensions of the learning organization questionnaire. $A d$ vances in Developing Human Resources, 5(2), 132-151. https://doi.org/10.1177/152 3422303005002002

Messmann, G., \& Mulder, R. H. (2015). Conditions for apprentices' learning activities at work. Journal of Vocational Education and Training, 67(4), 578-596. https://doi.org $/ 10.1080 / 13636820.2015 .1094745$ 
Nägele, C. (2013). Correlates and predictors of apprentices' perception of their workplace as learning place. An analysis of the first three years in apprenticeship. In S. Akoojee, P. Gonon, U. Hauschildt, \& C. Hofmann (Eds.), Apprenticeship in a globalised world. Premises, promises and pitfalls (pp. 95-98). Berlin, DE: LIT Verlag.

Nägele, C., \& Bierschenk, K. (2014). Höhere Berufsbildung im Bildungsraum Nordwestschweiz [Higher vocational education and training in the education area of Northwestern Switzerland]. Solothurn, CH: Pädagogische Hochschule FHNW, Institut Forschung und Entwicklung, Zentrum Lernen und Sozialisation.

Neuenschwander, M. P., Düggeli, A., Nägele, C., \& Frey, S. (2017). BEN II - 3. Zwischenbericht 2016 Bildungsentscheidungen und Bildungsverläufe von Jugendlichen (BEN) [Interim Report 2016 Educational decisions and educational pathways of young people (BEN)]. Solothurn, CH: Pädagogische Hochschule FHNW, Institut Forschung und Entwicklung, Zentrum Lernen und Sozialisation.

Neuenschwander, M. P., Gerber, M., Frank, N., \& Rottermann, B. (2012). Schule und Beruf: Wege in die Erwerbstätigkeit [School and occupation: Ways into employment]. Wiesbaden, DE: VS Verlag für Sozialwissenschaften.

Noe, R. A., Clarke, A. D. M., \& Klein, H. J. (2014). Learning in the twenty-firstcentury workplace. Annual Review of Organizational Psychology and Organizational Behavior, 1(1), 245-275. https://doi.org/10.1146/annurev-orgpsych-031413-091321

Parker, S. K. (2014). Beyond motivation: Job and work design for development, health, ambidexterity, and more. Annual Review of Psychology, 65, 661-691. https://doi.or g/10.1146/annurev-psych-010213-115208

Picot, G., \& Hou, F. (2013). Why immigrant background matters for university participation: A comparison of Switzerland and Canada. International Migration Review, 47(3), 612-642. https://doi.org/10.1111/imre.12038

Prümper, J., Hartmannsgruber, K., \& Frese, M. (1995). KFZA. Kurz-Fragebogen zur Arbeitsanalyse [KFZA. Short questionnaire for job analysis]. Zeitschrift für Arbeitsund Organisationspsychologie, 39, 125-131.

Raemdonck, I., Gijbels, D., \& van Groen, W. (2014). The influence of job characteristics and self-directed learning orientation on workplace learning: Job characteristics and self-directed learning orientation. International Journal of Training and Development, 18(3), 188-203. https://doi.org/10.1111/ijtd.12028

Rafferty, A. E., \& Jimmieson, N. L. (2010). Team change climate: A group-level analysis of the relationships among change information and change participation, role stressors, and well-being. European Journal of Work and Organizational Psychology, 19(5), 551-586. https://doi.org/10.1080/13594320903007869

Semmer, N. K. (1984). Streßbezogene Tätigkeitsanalyse: Psychologische Untersuchungen zur Analyse von Streß am Arbeitsplatz [Stress-related work analysis: Psychological studies to analyse stress at the workplace]. Weinheim, DE: Beltz.

Stalder, B. E., \& Carigiet Reinhard, T. (2014). Ausbildungsqualität aus Sicht von Lernenden und Betrieben in der Schweiz [Quality of learning at work from the point of view of apprentices and companies in Switzerland]. In M. Fischer (Ed.), Qualität in der Berufsbildung. Anspruch und Wirklichkeit. Berichte zur beruflichen Bildung (pp. 97-115). Bielefeld, DE: W. Bertelsmann Verlag. 
Stalder, B. E., \& Nägele, C. (2011). Vocational education and training in Switzerland: Organisation, development and challenges for the future. In M. M. Bergman, S. Hupka-Brunner, A. Keller, T. Meyer, \& B. E. Stalder (Eds.), Transitionen im Jugendalter: Ergebnisse der Schweizer Längsschnittstudie TREE (pp. 18-38). Zürich, $\mathrm{CH}$ : Seismo Verlag.

State Secretariat for Education Research and Innovation [SERI]. (2016). Vocational and professional education and training in Switzerland. Facts and figures 2016. Bern, $\mathrm{CH}$ : State Secretariat for Education, Research and Innovation (SERI).

Swiss Coordination Centre for Research in Education [SKBF CSRE]. (2014). Swiss Education Report 2014. Aarau, CH: Swiss Coordination Centre for Research in Education (SKBF CSRE).

Trede, I. (2016). Laufbahnentscheidungen von Fachfrauen und Fachmännern Gesundheit nach Abschluss Ihrer Beruflichen Grundbildung [Career decisions by women and health professionals after completing initial vocational training]. Dissertation Universität Bremen, Bremen, DE.

Vanthournout, G., Kyndt, E., Gijbels, D., \& Van den Bossche, P. (2015). Understanding the direct and indirect relations between motivation to participate, goal orientation and the use of self-regulation strategies during a formal training. Zeitschrift für Erziehungswissenschaft, 18(1), 89-106.

Verband Schweizerischer Schreinermeister und Möbelfabrikanten [VSSM]. (2017). Der Schreiner. Karriereleiter - Aufsteigen zu neuen Horizonten [The carpenter. Career ladder - Moving up to new horizons]. Zürich, CH: Verband Schweizerischer Schreinermeister und Möbelfabrikanten (VSSM), Bereich Berufsbildung.

Wang, Z., \& Fu, Y. (2015). Social support, social comparison, and career adaptability: A moderated mediation model. Social Behavior and Personality: An International Journal, 43(4), 649-659. https://doi.org/10.2224/sbp.2015.43.4.649

Wenger, E. (2008). Communities of practice. Learning, meaning, and identity. New York, NY, US: Cambridge University Press.

Wigfield, A., \& Cambria, J. (2010). Students' achievement values, goal orientations, and interest: Definitions, development, and relations to achievement outcomes. Developmental Review, 30(1), 1-35. https://doi.org/10.1016/j.dr.2009.12.001

Wigfield, A., Rosenzweig, E. Q., \& Eccles, J. S. (2017). Achievement values interactions, interventions, and future directions. In A. J. Elliot, C. S. Dweck, \& D. S. Yeager (Eds.), Handbook of Competence and Motivation (pp. 116-134). New York, NY, US: The Guilford Press.

Wolter, S. C., \& Zumbuehl, M. (2017). The native-migrant gap in the progression into and through upper-secondary education. Bonn, DE: IZA - Institute of Labor Economics.

Wrzesniewski, A., \& Dutton, J. E. (2001). Crafting a job: Revisioning employees as active crafters of their work. The Academy of Management Review, 26(2), 179-201. https://doi.org/10.2307/259118 


\section{Biographical Notes}

Dr Christof Nägele is a senior researcher at the Centre for Learning and Socialisation, Institute for Research and Development, School of Education at the University of Applied Sciences and Arts Northwestern Switzerland. His research interests focus on vocational orientation, career choice of young people, learning and career development of adults workers, individual, group level and structural resources in vocational education and training.

Dr Markus P. Neuenschwander is a Professor at the Centre for Learning and Socialization, Institute for Research and Development, School of Teacher Education at the University of Applied Sciences and Arts Northwestern Switzerland. His research focuses on the school-to-work transition, socialisation in the family, school, and vocational education and training.

M Sc Patsawee Rodcharoen is a junior researcher at Centre for Learning and Socialisation, Institute for Research and Development, School of Education at the University of Applied Sciences and Arts Northwestern Switzerland. Her interests focus on developmental and social aspects of vocational education and training, vocational integration, learning, and at-risk trajectories.

\section{Acknowledgement}

The State Secretariat for Education, Research, and Innovation (SERI) supported this study (contract number 13100028). The interpretations, conclusions, and recommendations are those of the authors and do not necessarily represent the views of the SERI. 